\title{
Labor Market Duality and the Impact of Prolonged Recession on Employment in Croatia
}

\section{Mislav Brkić}

Croatian National Bank, Croatia

mislav.brkic@hnb.hr

\author{
CroEconSur \\ Vol. 17 \\ No. 1 \\ June 2015 \\ pp. 5-45
}

Received: February 17, 2015

Accepted: June 8, 2015

Research Article

doi:10.15179/ces.17.1.1

\section{Abstract}

The term labor market duality can be used to describe different forms of labor market segmentation. Nevertheless, this term is most often used to describe the segregation between permanent employees and workers employed on a temporary basis. There is a consensus in the literature that labor market duality most often occurs after governments engage in asymmetric reforms of the labor market legislation, which significantly liberalize the use of temporary contracts, while retaining a high level of employment protection for permanent workers. This paper analyzes whether in Croatia as a country with relatively rigid labor market legislation there are signs of labor market duality. The analysis is motivated by the recent data on employment flows showing that companies have intensified temporary hiring in recent years, which might be considered as a sign of increasing labor market duality. However, this paper discusses labor market developments in the context of persistent recession, taking into account that such changes in the 
employment flows could be a cyclical phenomenon reflecting high risk aversion of companies.

Keywords: labor market duality, employment protection, recession, Croatia, $\mathrm{EU}$

JEL classification: J21, J80, K31

\section{Introduction}

The labor market duality most often appears in countries with rigid labor market legislation. In such legislative environment companies may be more inclined to hire temporary workers and the share of temporary workers in the total employment will eventually increase. Namely, if labor code foresees long and complicated procedures for dismissals of redundant permanent employees, companies will be slow to adjust to economic slowdown which might threaten their solvency. In order to preserve some room for cost reduction in case of need, firms might increase the share of temporary workers which would result in an increase in the share of temporary employees in the total employment in the economy. Since such workers will be treated by firms as flexible part of the production factors, temporary workers will be in an inferior position compared to other employees and labor market duality might materialize. Employing workers under temporary contracts will be more attractive for companies when the employment protection for regular contracts is high, and legal restrictions for the use of temporary contracts are low.

A number of possible negative consequences of the labor market duality are empirically identified, both for workers and for firms. For instance, temporary workers are more exposed to the risk of losing their jobs, they usually enjoy lower salaries and fewer other benefits, such as on job education programs, compared to regular employees. Young workers can be particularly affected by this phenomenon during crisis episodes, considering that they are more often employed under temporary contracts than workers from other age groups. 
Employers might also experience some negative effects of increased reliance on temporary workers, principally in terms of lower productivity growth.

The main goal of this paper is to analyze whether there are signs of labor market duality in Croatia, given its relatively rigid labor market legislation. As employment dynamics have been under the strong influence of economic contraction in recent years, the issue of labor market duality is considered taking into account the adverse macroeconomic developments. Given the existence of large external and internal imbalances, the outbreak of the global financial crisis initiated a deep recession in Croatia which led to a significant worsening of labor market conditions. As in other countries with similar characteristics, the employment contraction was especially pronounced in the activities of construction and retail, which previously relied on buoyant domestic demand. A noticeable decline in the number of employees was recorded in all other economic activities, except in those few dominated by the public sector. Croatia stands out among peer countries in that it experienced pronounced annual employment drop in every year in the period between 2009 and 2013. The exceptional persistence of the current recession points to existence of certain unfavorable factors that especially negatively affect the economic developments in Croatia. Among the key obstacles to growth are the need for deleveraging of domestic entities after the fast accumulation of debt in the previous period and the long and ineffective fiscal consolidation. Although the government has implemented several restrictive fiscal measures, the progress in the reduction of fiscal imbalances has not yet been achieved, which in turn negatively weighs on the confidence of domestic economic agents and foreign investors (International Monetary Fund, 2014). Moreover, the external sector cannot provide the vital stimulus to economic recovery due to fragile recovery of the key trading partners, but also insufficient export capacities, unfavorable geographic orientation and product specialization of Croatian exports (European Commission, 2013).

In addition to strong employment contraction, during the current recession significant changes in the employment flows have been observed. Specifically, in 
recent years companies have significantly accelerated hiring based on temporary contracts, which leads to a gradual increase in the share of temporary workers in the total employment. This paper analyzes the data on employment flows from the beginning of recession until the end of 2014 in order to gather more detailed insight into the recent intensification of temporary employment. This way it is estimated whether the more frequent use of temporary contracts is a general trend among companies or simply a result of more pronounced seasonal hiring in service activities. Furthermore, this paper deals with the relative dynamics of temporary and permanent employees during the recession, both for Croatia and other Member States, in order to find whether the temporary employees were hit relatively harder by the recession, which would be a feature of dual labor market as suggested by the literature. Based on the analyzed data the conclusion is derived on whether there has been strong evidence of labor market duality in Croatia.

This paper briefly discusses the labor market legislation in Croatia, with special focus on employment protection for regular contracts, in order to determine whether there are institutional preconditions for the duality of the labor market. The government took some important steps in order to increase flexibility of the labor market legislation in recent years, as part of the general endeavor to improve the business climate in Croatia. This paper covers some key aspects of those legal reforms and discusses their possible impact as regards the potential labor market duality. The employment protection legislation in Croatia has been estimated in a few instances (Biondić, Crnić and Martinis, 2002; Matković and Biondić, 2003; Tonin, 2009; Tomić and Domadenik, 2012; Croatian National Bank, 2013; and Kunovac, 2014), but this paper covers primarily the changes provided with the new Labor code (Narodne novine, 93/2014) ${ }^{1}$ which was not covered by the existing papers in detail. The main finding of the analysis is that the new labor market reform is the first reform of that kind after a long time that has to some extent reduced the employment protection for permanent employees.

1 For legal aspects of the new Labor code see Potočnjak (2014). 
The paper is structured as follows. After the introduction, a review of the extensive literature of dual labor markets is briefly presented. The third chapter deals with the impact of recession on the labor market in Croatia ${ }^{2}$, while the fourth chapter discusses the possible existence of the labor market duality in Croatia. The fifth chapter presents the main findings of the paper.

\section{Labor Market Duality: A Literature Review}

The existing problem of labor market duality in several European countries emerged gradually following the changes in labor market legislation that have occurred over the past five decades. In the first phase, during the 1960s and the first half of 1970s, a number of European countries considerably increased the level of employment protection (Bentolila and Bertola, 1990). The adverse consequences of the 1973 oil shock clearly demonstrated that higher rigidity of the labor market legislation resulted in the lower ability of companies to adjust to changing economic conditions. The oil shock resulted in a sharp deceleration of economic growth which negatively reflected on business confidence. In such an environment companies were eager to reduce the production costs by cutting employment, but the adjustment process was rather slow due to previously increased employment protection. As a result, companies were reluctant to engage in new hiring which contributed to a relatively high unemployment rate. Many authors (e.g., Giersch, 1985) held that the rigid labor market legislation was the main factor behind dismal performance of labor markets in Europe in that period.

In order to respond to firms' demands for higher flexibility and to boost employment, policy-makers started to implement labor market reforms (Bentolila and Dolado, 1994; Blanchard, Jaumotte and Loungani, 2013). However, as comprehensive reforms were difficult to implement due to a strong resistance of labor unions, in most cases those reforms were asymmetric, addressing only

2 For a detailed analysis of the impact of economic crisis on Croatian labor market see Vukšić (2014). 
provisions related to temporary workers (Saint-Paul, 1997). Specifically, such reforms were based on significant liberalization of the temporary contracts, which provided companies with higher flexibility in regulating the number of employees, while existing permanent employees preserved a high level of employment protection ${ }^{3}$. As shown in Bentolila and Dolado (1994), the surge in temporary employment after the implementation of asymmetric reforms was particularly evident in countries which were previously characterized by highly rigid labor markets, such as Spain and France.

Boeri (2010) also finds the connection between the dual labor markets and the implementation of marginal reforms, and states that such reforms were driven by efforts to reduce the employment protection measured by the EPL index (Employment Protection Legislation), which is estimated by the OECD. Namely, as the EPL index was the aggregate measure of rigidity which did not separately assess the level of employment protection for different types of contracts, governments could successfully reduce the index by liberalizing temporary employment, without changing the regulatory treatment of permanent workers. However, in 2013 the OECD switched from calculating the aggregate EPL index to calculating the two separate indexes: EPT index (employment protection temporary contracts) that deals with provisions covering temporary employment, and EPRC index (employment protection regulator contracts, including collective dismissals) that assesses the rigidity of legislation concerning regular contracts. With this adjustment the OECD prevented countries from reducing the overall score for labor market rigidity by changing only provisions dealing with temporary contracts.

There is a consensus in the literature that asymmetric reforms which cause the labor market duality do not have clear positive impact on employment and productivity. For example, Boeri and Garibaldi (2007) argue that partial reforms increase the cyclical volatility of employment along the business cycle, but that

3 The asymmetric labor market reforms were supported by both employers, since they were allowed higher flexibility in hiring and firing temporary workers, and labor unions, given that high employment protection for permanent workers was not affected by the reforms. 
they do not have a positive impact on the average demand for labor. Although the employment usually increases immediately after the liberalization of temporary contracts, such a trend reverts in the recessionary phase when sudden destruction of previously created temporary jobs takes place. Specifically, when recession begins, companies attempt to reduce production costs, which foremost affects temporary workers since they can be dismissed much easier than permanent workers. Therefore, Boeri and Garibaldi (2007) conclude that the liberalization of temporary contracts results in higher cyclical volatility of employment, while the positive effect on the average number of employees is only temporary (the honeymoon effect). Moreover, Boeri and Garibaldi (2007) show that asymmetric labor market reforms might have a negative impact also on the average labor productivity. Namely, the authors suppose that companies will hire temporary workers during the economic expansion, on the part of the labor demand curve where marginal productivity of labor is diminishing. Given that marginal productivity of every additional worker is lower, the average level of productivity will decrease as the number of temporary workers increases. Blanchard, Jaumotte and Loungani (2013) also find a possible negative impact of marginal reforms on labor productivity, but the negative effects stem primarily from the fact that employers are less willing to invest in education of temporary workers, which reflects on their productivity growth.

Bentolila and Dolado (1994) agree that excessive employment instability might negatively reflect on the development of human capital, and argue that increased bargaining power of permanent workers could be an additional side effect of asymmetric reforms. Namely, given that such reforms liberalize the hiring of temporary workers which represent a flexible part of production factors, the risk of job loss for permanent employees declines, which further strengthens their bargaining position. This finding was recently empirically confirmed by Bakker and Zeng (2013) who find that in countries with dual labor markets the adjustment of companies during the recent crisis was more often based on temporary employment cuts than on the reduction of average wage, which can 
be explained by the influence of insiders, the permanent workers. Garibaldi and Taddei (2013) find that after the implementation of asymmetric labor market reforms companies start to substitute permanent workers with less expensive temporary workers, with the basic motivation of cost reduction. The unfavorable result of such substitution is a decrease in the number of available permanent job positions, and that in turn makes it more difficult for temporary employees and unemployed to find a stable, long-term employment. Nevertheless, Garibaldi and Taddei (2013) bring up some potentially positive effects of temporary employment for both workers and firms. Specifically, the liberalization of temporary contracts could facilitate the transition of young people from education to employment, while the benefit for employers is that such contracts allow a certain time period for the evaluation of candidates for permanent positions.

The evidence of labor market duality is found even in the United States which is characterized by highly flexible labor market. The labor market segmentation in the United States cannot be explained by asymmetric employment protection like in several European countries, but by the coexistence of high quality and low quality jobs. For example, Doeringer and Piore (1971) describe labor segmentation in the U.S. as a division between the employees of the primary sector, who usually work for manufacturing firms which offer high wages, job security and opportunity for internal promotion, and the workers of the secondary sector, typically employed in elementary occupations in service activities, who are exposed to job insecurity and generally much worse working conditions. Such workers may enter into a vicious cycle given that their unstable work histories, as well as lack of human capital due to low availability of onthe-job training in the secondary sector, will prevent them from entering the primary sector (Gordon, 1972; Bluestone, 1970). Some authors point out that discrimination, especially racial discrimination, is one of the main reasons why certain groups show limited upward mobility and stay trapped in the secondary sector permanently (Harrison, 1973). 
A couple of papers deal with the rigidity of labor market legislation and with the potential existence of the labor market duality in Croatia. For example, Rutkowski (2003) discusses the impact of legislation on labor market performance and states that the high level of employment protection is one of the main factors behind the slow job creation and high unemployment in Croatia. Namely, since employers are concerned that it would be difficult to dismiss an unproductive employee, they are very careful when hiring workers which also results in more frequent use of temporary contracts. Similarly, Tomić and Domadenik (2012) analyze the employment prospects of different groups of job seekers taking into account the influence of rigid labor market legislation. Authors find evidence of adverse selection in the Croatian labor market for unemployed job seekers, in the sense that employers consider their labor market status as a signal of their lower productivity. Having in mind the high firing costs in case such workers prove unproductive, employers are less willing to hire unemployed workers and that in turn negatively weighs on employment prospects of that group of job seekers. Šošić (2004) analyzes the database of the Financial Agency (FINA) for the period from 1994 to 2001 and finds evidence of the labor market duality in Croatia, where a key source of duality is a pronounced difference in the employment stability depending on the type of firm ownership. In particular, Šošić finds that the dominant share in the total employment loss in the reference period was registered in the so-called new private sector, while the employment adjustment in public enterprises and recently privatized firms was progressing very slowly. Šošić concludes that the liberalization of atypical employment contracts stemming from the labor market reform of 2003 might further increase the labor market segmentation in Croatia.

Franičević (2011) considers the labor market developments during the recent recession and states that the asymmetric reforms of the labor market legislation implemented in the pre-crisis period had created a gap between temporary employees and privileged permanent employees. Franičević registers that in the initial phase of the crisis the highest burden of the employment adjustment 
had been felt by the temporary workers, but afterwards a strong inflow into unemployment was also registered among workers who were previously employed under regular contracts. World Bank (2010) also partly ascribes the strong employment contraction at the beginning of recession to layoffs of temporary employees, whose number increased during the years prior to the outbreak of the global financial crisis. Finally, Matković (2013) discusses the relative status of temporary workers in the Croatian labor market, based on the Labor Force Survey data for the period 1997-2008. The author finds that temporary contracts are frequently used in the peripheral part of the private sector for hiring lowskilled workers in activities such as accommodation and food service, retail trade, construction and agriculture. The author also notes that temporary workers enjoy less favorable status compared to regular workers in terms of the salary level, job security and overall satisfaction in the workplace.

This paper contributes to the existing literature on labor market duality in Croatia by analyzing the data from the Labor Force Survey for the entire period of current recession, focusing separately on the dynamics of temporary and permanent employment. In that way, while also taking into account employment dynamics in other Member States, this paper derives the conclusion on whether the signs of labor market duality have been identified in Croatia during the recession. Furthermore, an important contribution of this paper is that it identifies, based on a detailed analysis of employment flows, major changes in the structure of new employment. Namely, in the later phase of the current recession companies have intensified the hiring on temporary basis while at the same time they have slowed down hiring under permanent employment contracts, which may be considered as a sign of strengthening of the labor market duality. 


\section{Impact of the Prolonged Recession on Employment in Croatia}

\subsection{Cyclical and Structural Determinants of the Employment Contraction}

When analyzing the employment dynamics in the period after the outbreak of the global financial crisis, one has to bear in mind the magnitude of output contraction which was registered in Croatia in that period. Namely, from the beginning of the recession to the end of 2013 the real GDP cumulatively declined by more than 12 percent, which is one of the worst output performances in the entire $\mathrm{EU}^{4}$. Given the strong positive correlation between the real economic activity and the labor market, Croatia is also among the countries which recorded the strongest employment contraction in recent years.

Figure 1: Cumulative Change in Real GDP and Employment in the Period 2008-2013

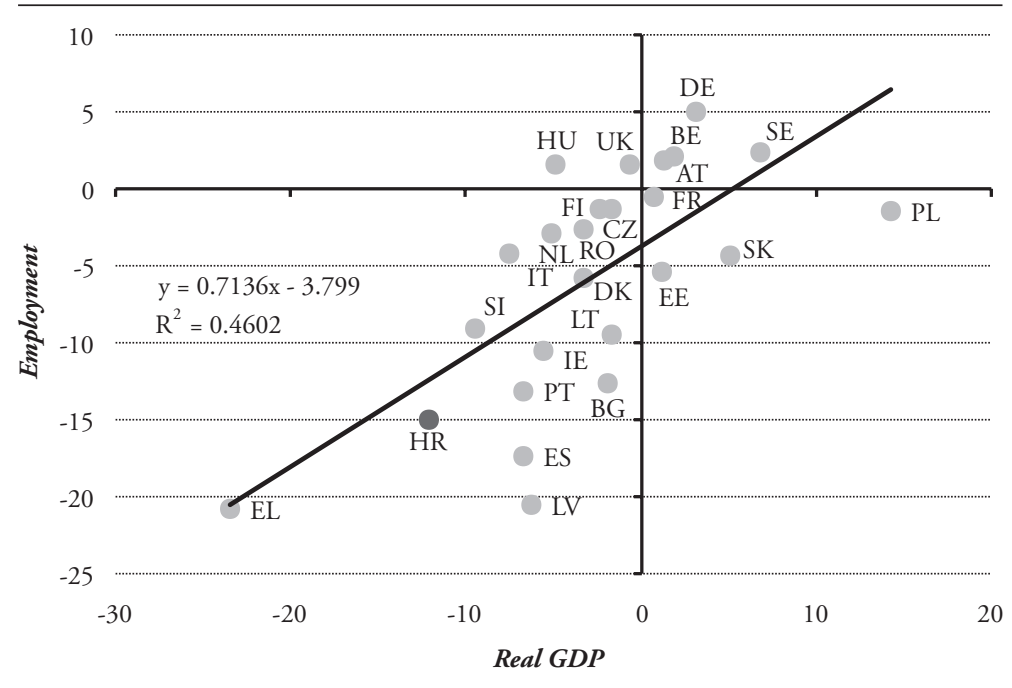

Sources: Eurostat and author's calculation.

4 A cumulative fall in real output is calculated as a percentage change of seasonally adjusted real GDP in the fourth quarter of 2013 relative to the seasonally adjusted real GDP in the third quarter of 2008. 
Figure 1 clearly shows that there have been major differences between the Member States regarding the depth of recession and employment destruction in the period after the intensification of the global financial crisis. It would therefore be beneficial to investigate whether some macroeconomic features of the Member States' economies determined the intensity of negative developments after the global financial crisis affected the EU. Table 1 shows the overall change in the number of employees in the Member States during the recession, together with a few important macroeconomic indicators for those countries for the period prior to the crisis. It is obvious that employment contraction was especially strong in those countries which previously stood out with excessive macroeconomic imbalances, such as Greece, Spain, Portugal, Baltic countries and Croatia.

Regression estimation of determinants of the fall in employment, with key macroeconomic indicators for the pre-crisis period as independent variables, confirms that the initial level of imbalances can partly explain the differences in employment dynamics among EU Member States during the recession. The Table 2 shows the results of the estimation of a very simple model containing the employment contraction in EU Member States as a dependent variable, and the current account balance for the period 2004-2008 and the increase in the net external debt in the same period as explanatory variables. The model contains only two independent variables in order to save degrees of freedom, given only 26 observations $s^{5}$. The current account balance and the net external debt are chosen because these two variables can reflect a number of other imbalances, such as excessive domestic demand, strong growth in the private sector debt, overheating of the housing market and the loss of competitiveness.

5 Malta and Luxembourg are excluded from the estimation since the net external debt is significantly negative in both countries, which is related to the fact that both countries serve as financial centers. 


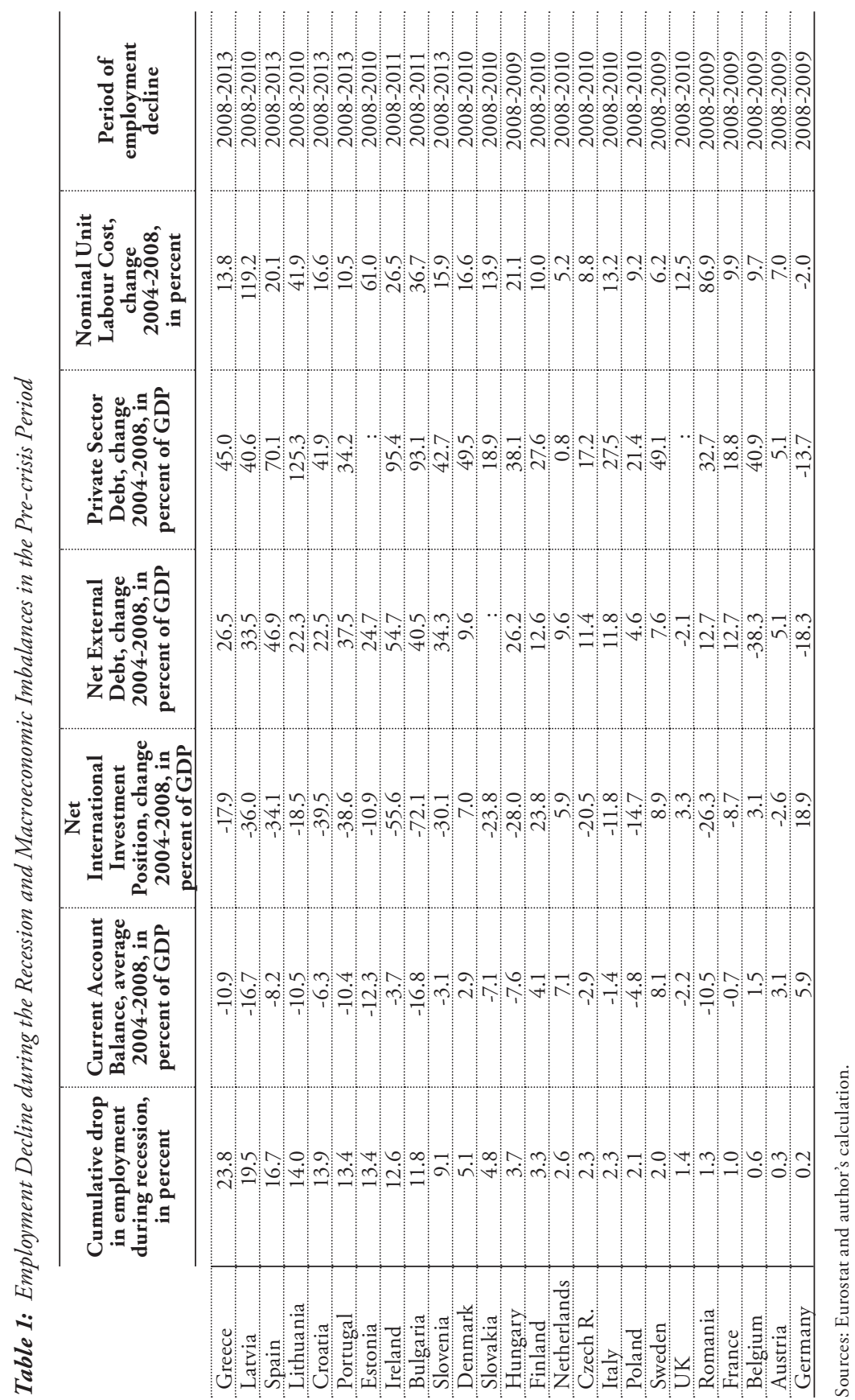


Table 2: Estimation of a Simple Model of Employment Dynamics in EU Member States during the Recent Recession

\section{Dependent variable:}

Employment contraction, following the outbreak of the global financial crisis, in \%

\section{Independent variables:}

Current account balance, average for 2004-2008, in percent of GDP

Net external debt, accumulation in 2004-2008, in percent of GDP

Constant

Adjusted R-Squared

\section{DW Statistics}

Note:

${ }^{* *} \mathrm{p}<0,05$; ${ }^{* * *} \mathrm{p}<0,01$;

Source: Author's calculations.

The coefficients for both variables have intuitive signs. The coefficient for the net external debt is positive, suggesting that a stronger debt accumulation in the pre-crisis period implied a greater deleveraging afterwards, causing a deeper economic slump and a more pronounced employment contraction. The current account balance, on the other hand, has a negative coefficient, which might suggest that a more negative current account balance prior to the crisis entailed a stronger correction of the domestic demand after the crisis escalated, which in turn led to a more severe drop in output and employment. However, the regression results should be considered as only indicative since this simple model clearly suffers from many econometric flaws.

In several Member States the current account deficits were higher than what is acceptable for countries of such levels of relative income, since they were a reflection of overheating of the domestic demand in those economies. An extended period of buoyant domestic demand initiated unfavorable adjustments in the economic structure, given that output and employment expanded especially in those sectors which relied on strong domestic demand, such as construction and 
retail (Sun, Mitra and Simone, 2013). Furthermore, the excessive current account imbalances were mirrored in the strong accumulation of net external debt which implied substantial refinancing needs and therefore high vulnerability to external shocks. After the escalation of the global financial crisis in the late 2008 those economies were forced to abruptly correct the prevailing imbalances, and that in turn caused significant fall in the output and employment, particularly in those activities which previously benefited from strong domestic demand ${ }^{6}$.

According to the data presented in Table 1 one can notice that at the moment when financial crisis erupted, Croatia was showing all signs of excessive external imbalances, especially in terms of a high current account deficit and quick accumulation of the external debt. The widening of harmful external imbalances in the pre-crisis period was followed by the emergence of domestic imbalances, such as rising private sector indebtedness, overheating of the housing market and the unfavorable rebalancing towards non-tradable sectors (Croatian National Bank, 2008). Due to the existence of macroeconomic imbalances, Croatian economy was highly exposed to the risk of sudden external shocks, and that risk materialized with the start of the global financial crisis. The negative effects of the crisis manifested through the slowdown in capital inflows, sudden decline in international trade and significant fall in business and consumer confidence, and all that in turn resulted in a strong contraction of aggregate demand (Croatian National Bank, 2010). Therefore, it could be argued that a massive external shock in combination with country-specific vulnerabilities initiated a deep and persistent recession which led to a significant deterioration of the labor market conditions.

Employment has been declining continuously since the start of the crisis in almost every sector of the economy. When analyzing employment dynamics according to NACE classification of activities, it is noticeable that the strongest fall is registered in construction and in the category wholesale, retail trade, repair of motor vehicles and motorcycles (Table 3). To be precise, in the period from 
2009 to 2013 the number of employees in construction and trade shrank by more than 100 thousand, which entirely erased the total job creation in those activities during the economic expansion from 2002 to 2008. Interestingly, other countries that were also experiencing the overheating of economic activity prior to the crisis, such as Greece, Spain, Portugal, Ireland and Baltics, have also registered severe decline of employment in construction and trade in recent years (Table 4).

Table 3: Number of Employees, by Economic Activity, 2008 and 2013

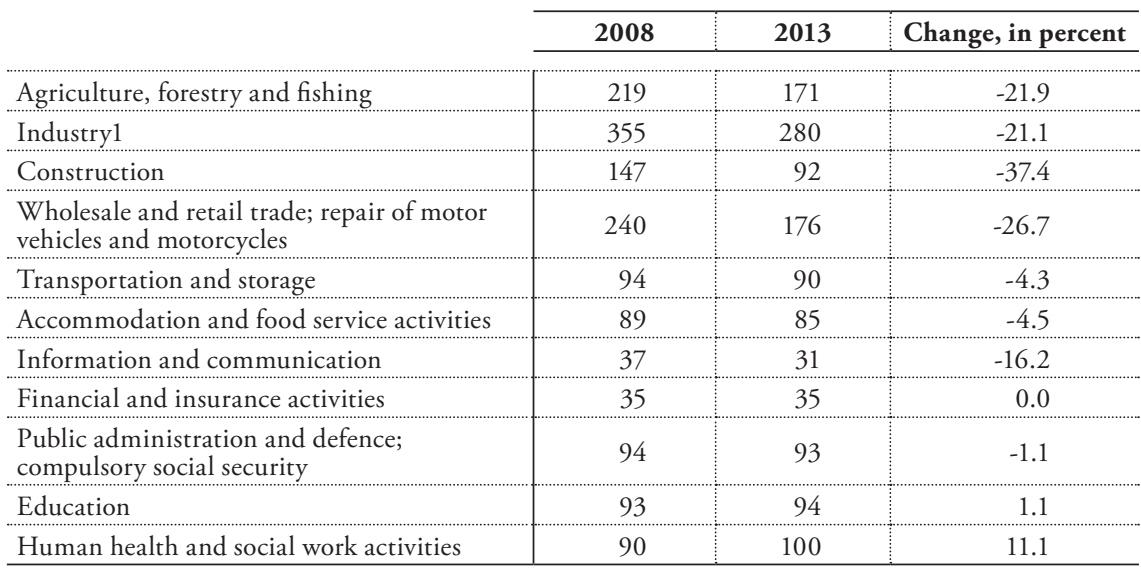

Note: Industry is considered as a wider concept which encompasses four categories of the national classification of activities (NACE): Mining and quarrying (B); Manufacturing (C); Electricity, gas, steam and air conditioning supply (D); Water supply, sewerage, waste management and remediation activities (E).

Source: Labor Force Survey, Central Bureau of Statistics.

The adverse domestic economic developments and subdued foreign demand reflected also on the industrial output in Croatia, which resulted in the number of employees in the industry cumulatively falling by 21 percent or by 75 thousand in the period 2009-2013. Table 3 shows that the recession has not affected the employment in activities dominated by the public sector: public administration and defense, education and human health activities. In fact, the total employment in those activities slightly increased during the recession, while in other economic activities the employment shrank by more than 250 thousand. 
Accordingly, it could be argued that the private sector has borne the full burden of the employment adjustment during the crisis. In most other Member States the adverse impact of recession on employment in activities dominated by the public sector was also subdued, which could be explained by the fact that employment in those activities typically does not fluctuate to a great extent over the business cycle. However, in several Member States which relied on financial assistance from the IMF and the EU, the employees of the public sector employment have been affected by the recession. Namely, the macroeconomic adjustment programs implemented by Latvia, Greece and Portugal were based, among other measures, on reduction of the public sector wage bill, and that was partly achieved by dismissing a certain share of public sector servants (Table 4).

\subsection{Changes in the Structure of New Employment}

The protracted recession, besides adversely affecting the employment dynamics, has also caused noticeable changes in the structure of new employment. Namely, the data on flows in the unemployment register published by the Croatian Employment Service (CES) show that the companies have significantly increased the use of temporary contracts in new hiring. Beginning with 2010, the number of exits from the unemployment register based on temporary employment has been rising very strongly, while at the same time the number of hiring under the permanent employment contracts has been steadily decreasing. 


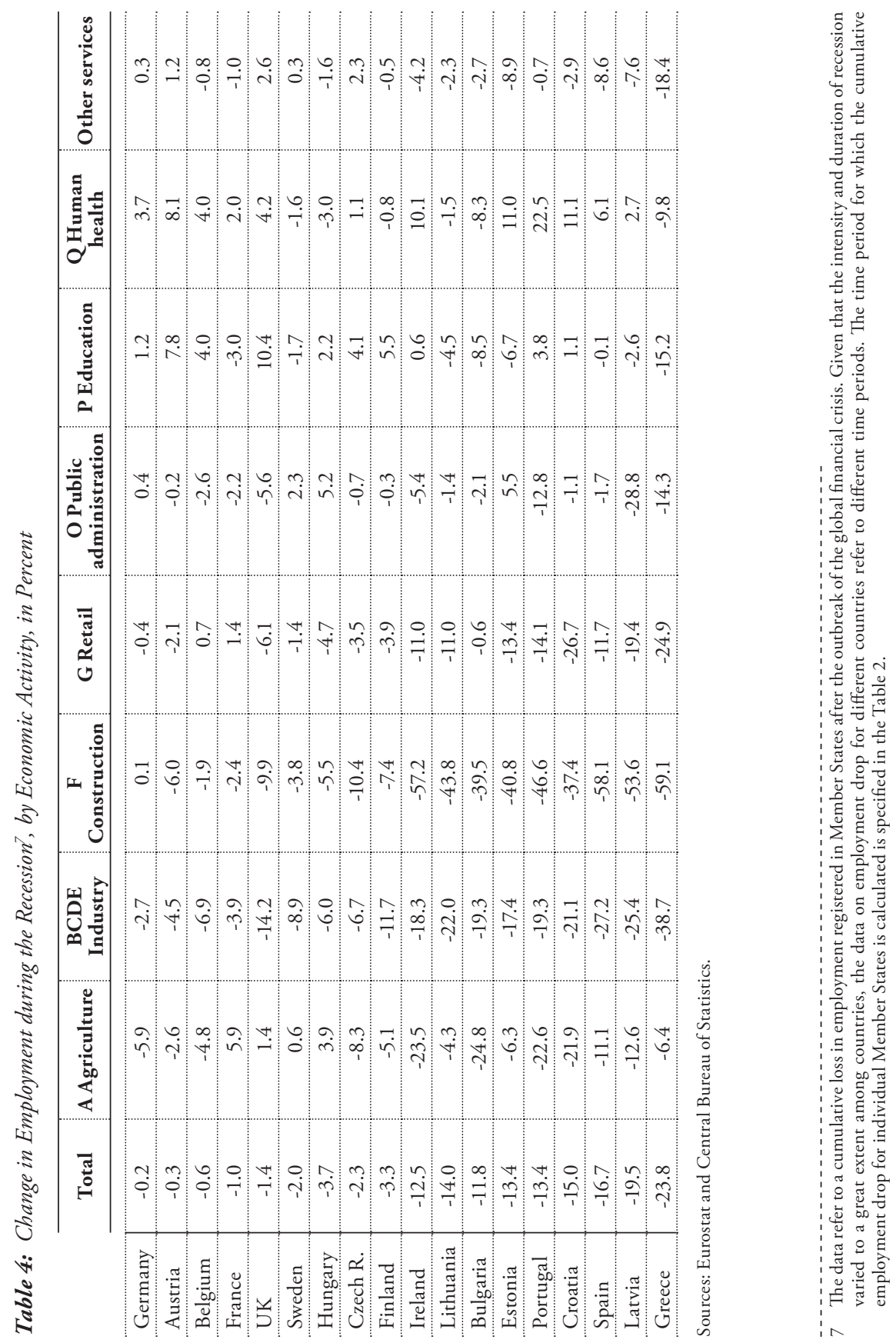


More frequent use of temporary contracts reflected on the statistics of the main causes of new entries to the unemployment register. Namely, since the employment on temporary basis is growing rapidly, the expiration of the employment contract has been by far the most frequent reason for new applications to the unemployment register in recent years. For example, in 2007 the CES registered 75 thousand new entries into the register arising from the expiration of the temporary employment contract, while in 2014 the expiration of the temporary employment contract was the cause of almost 150 thousand new entries. Therefore, it could be argued that more frequent use of temporary contracts has contributed notably to the higher volatility of the labor market over the last couple of years (Figure 2). Such developments could be interpreted as an indication of increasing labor market duality. In the following chapter the data on employment flows are analyzed in more detail in order to determine the background of recent trends and to discuss whether there is evidence of labor market duality in Croatia.

Figure 2: Flows in the Unemployment Register

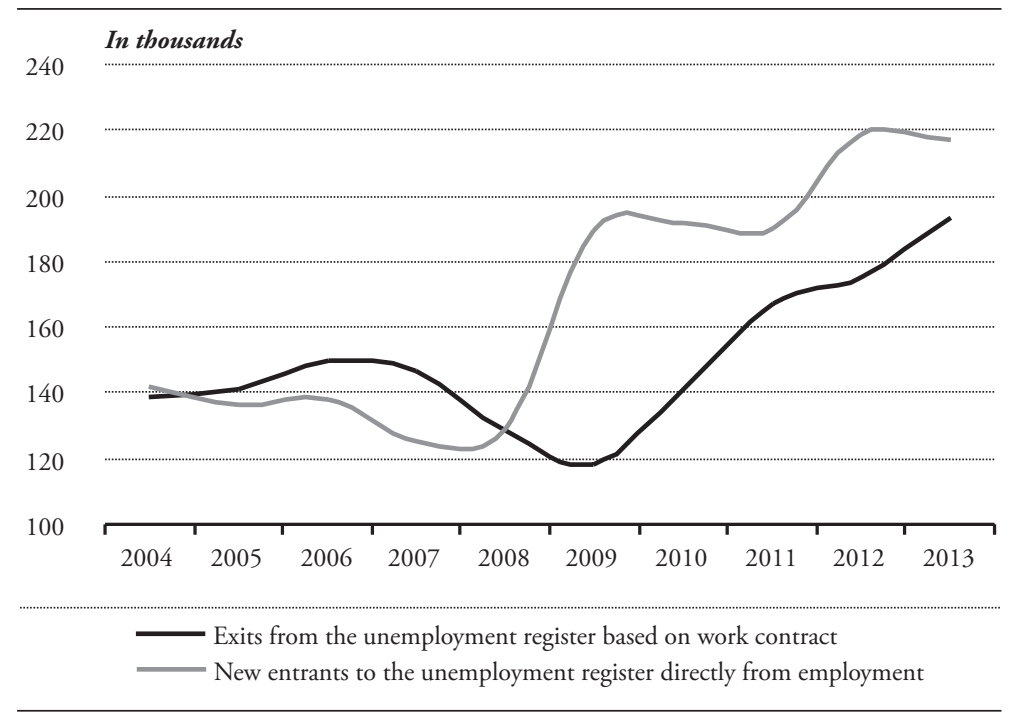

Source: Croatian Employment Service. 


\section{Analysis of the Potential Labor Market Duality in Croatia}

The previous chapter briefly discussed the strong negative impact of the recent recession on the Croatian labor market. This chapter analyzes whether during this period some particular groups of employees were privileged in a sense that they enjoyed higher level of job security than other groups of employees. The special focus will be on the comparison between the relative positions of employees depending on the type of the employment contract, but some other potential forms of labor market segmentation will also be considered. But first, a brief overview of the labor market legislation in Croatia is presented in order to define whether the current institutional setup stimulates the emergence of the labor market duality.

\subsection{Rigidity of the Labor Market Legislation in Croatia}

In the literature review it is noted that the labor market duality most often arises when companies, due to a high level of employment protection for permanent employment contracts and at the same time a flexible legal framework for temporary contracts, rapidly increase their reliance on temporary workers. Croatia is usually considered as a country with rigid legal protection of employment. A relatively high level of minimum wage, strong influence of labor unions, long procedures in case of dismissals of permanent workers and high unemployment rate suggest that Croatia has a relatively rigid labor market. Such features of the labor market correspond to the so-called continental model of labor markets that is dominant in advanced economies of the Western Europe. The continental model is opposed to the so-called Anglo-Saxon model of labor markets which is characterized by high fluctuation of employees, low level of employment protection, and a generally low unemployment rate (Blanchard, Jaumotte and Loungani, 2013). 


\subsubsection{Legal Treatment of Different Employment Contracts prior to Recent Reforms}

The rigidity of the labor market legislation is most evident when it comes to the termination of permanent employment contracts. For instance, the Labor code from 2009 (Narodne novine, No. 149/2009) stipulated that an employer may dismiss a permanent worker due to business or personal reasons only if it is not possible to retrain the worker for alternative workplace within the company. Moreover, when an employer decides on the termination of the contract due to business or personal reasons, he has to take into account personal characteristics of the employee, such as his seniority, age, physical disability and maintenance obligations lying upon the employee. A provision according to which a worker dismissed due to business reasons has priority in case a company decides to hire a worker for the same job position within the six months after the dismissal is also very rigid for employers. Nevertheless, it is important to notice that most of the abovementioned restrictive provisions concern only companies with twenty or more employees, meaning that smaller companies are not obliged to respect those provisions.

In June 2013 the revised Labor code (Narodne novine, No. 73/2013) entered into force, which was presented as the first stage of the comprehensive labor market reform. The main goal of the revised law was to reduce the rigidity of the labor market legislation according to international standards in order to positively reflect on the overall business environment in Croatia. However, the effects of the law were limited since it affected almost exclusively the provisions regarding temporary contracts. More specifically, the companies were allowed to justify more easily the first application of the temporary contract, and the provision which limited the duration of the first temporary contract to three years was removed. Some minor adjustments to the provisions covering collective dismissals were also implemented ${ }^{8}$. Kunovac (2014) using the methodology of the OECD estimates that the legal adjustments of June 2013 lowered to some

\footnotetext{
8 For example, a maximum postponement in the case of collective dismissal, which public employment service can require from the employer, has been shortened from 90 to 30 days.
} 
extent the rigidity of the labor market legislation in Croatia, but that it was almost entirely the result of the liberalization of temporary contracts. Given that adjustments to the provisions addressing regular contracts were not implemented at that stage, the revised Labor code actually increased the relative appeal of temporary contracts compared to regular contracts. Such design of the reform is comparable to labor market reforms implemented in Italy, Spain and France during the 20th century, which contributed to the appearance of labor market duality in those countries.

\subsubsection{Potential Effects of the New Labor Code of 2014}

In August 2014 the new Labor code (Narodne novine, No. 93/2014) entered into force, which was supposed to enshrine more flexibility into the framework for regular employment contracts and to increase the flexibility of other aspects of the labor market legislation. More specifically, the new law aims to reduce the employment protection for permanent contracts, facilitate the procedures in case of collective dismissals, and to allow for more flexibility in the definition of working hours. The new law also revised the provisions which deal with the activities of agencies for temporary employment (Croatian National Bank, 2014).

With regard to adjustments in the field of dismissals of permanent employees, the new law removes the provision which obliges the employer to educate the worker for an alternative job position prior to realization of a dismissal due to business or personal reasons. Moreover, the new Labor code reduces the maximum amount of penalty for employer in case the court decides that the dismissal was unjustified, from 18 to 8 average monthly salaries. Croatian National Bank (2014) estimates that after those revisions the rigidity of the labor market legislation has decreased, which has improved the relative position of Croatia according to internationally comparable indexes of labor market performance? ${ }^{9}$ That was the first reduction of employment protection for regular contracts in Croatia after the labor market (2014). 
reform of 2003, when the provisions regarding notice periods and severance pay were revised ${ }^{10}$. Further adjustments were made in the field of collective dismissals which should facilitate the process of corporate restructuring in times of financial difficulties ${ }^{11}$.

Therefore, the Labor code which entered into force in August 2014 has reduced the rigidity of employment protection applied to regular contracts, and that in turn improved the relative flexibility of the labor market legislation in Croatia. However, several restrictive provisions covering dismissals of permanent employees remained in force. For example, the employer is still obliged to inform the workers' council if he plans to dismiss a particular worker, personal features of a worker should be taken into account when considering dismissal of a worker due to business reasons, and a dismissed worker has the priority in case a company decides to hire for the same position within the six months after the dismissal. Nevertheless, one should bear in mind that those restrictive provisions only relate to companies which employ twenty or more workers, so the smaller companies are not affected by them.

\subsection{The Use of Temporary Contracts in Croatia}

\subsubsection{The Share of Temporary Workers in Total Employment}

Although the employment protection legislation in the pre-crisis period was relatively rigid by international standards, companies were usually ready to hire workers on a permanent basis. Compared to other Member States, the share of temporary employees was not especially high and in 2008 it stood at 12 percent, which was slightly lower than the average value for the EU (Figure 3).

10 For details about the labor market reform of 2003 see Matković and Biondić (2003).

11 Namely, the new law removes the obligation for the employer to develop a social security plan for redundant workers. Moreover, the new law foresees some adjustments which will not directly affect the level of employment protection, but which could nevertheless have some favorable effects on companies. For example, in order to accelerate the process of employment adjustment, the new law stipulates that the notice period runs even during the annual leave and paid leave. The new law also includes provisions which limit the possibility for employees to avoid dismissal with the use of sick leave. 
For comparison, in Spain the share of temporary employees in the total number reached 30 percent prior to crisis, which is partly a result of asymmetric labor market reforms implemented in earlier decades.

In Croatia the temporary contracts are much more common among young workers than in other age groups. The data from the Labor Force Survey for 2008 show that the share of temporary workers in total employment for the age group 15-24 surpassed 30 percent, while for the age groups 25-49 and 50-64 the temporary workers' shares were 9.8 percent and 3.4 percent, respectively. However, during the recession the share of temporary workers in total employment increased for all three age groups. Taking into account the frequency of temporary contracts in different economic activities, it is evident that such employment contracts are most common in manufacturing, wholesale and retail trade, and in the activities of accommodation and food service. Furthermore, when analyzing the use of temporary contracts by main occupations, it is noticeable that such contracts are most frequently used for employing workers of service and sales occupations, workers of elementary occupations and industrial workers ${ }^{12}$.

Given the dominance of permanent employees in total employment prior to the outbreak of global financial crisis, Croatian companies could not achieve sufficient cost reduction by dismissing only temporary workers. In such circumstances the adjustment of firms to recessionary environment resulted in significant contraction of the number of permanent workers. For example, in 2013 the average number of employees with regular contracts was lower by 240 thousand compared to the average number in 2008. On the other hand, the number of temporary employees increased somewhat during the crisis, which is a consequence of a more intensive use of temporary contracts, especially from the 2010 onwards. The result is the increase in the share of temporary employees, as shown in Figure 3. Several other Member States have also registered divergent dynamics of the number of employed persons depending on the type of employment contract. Namely, as shown in the Table 4, Czech Republic, 
Ireland, Latvia, Hungary and Slovakia recorded an increase in the number of temporary workers during the recession, at the time when the total employment was shrinking.

Figure 3: The Share of Temporary Employees in the Total Employment

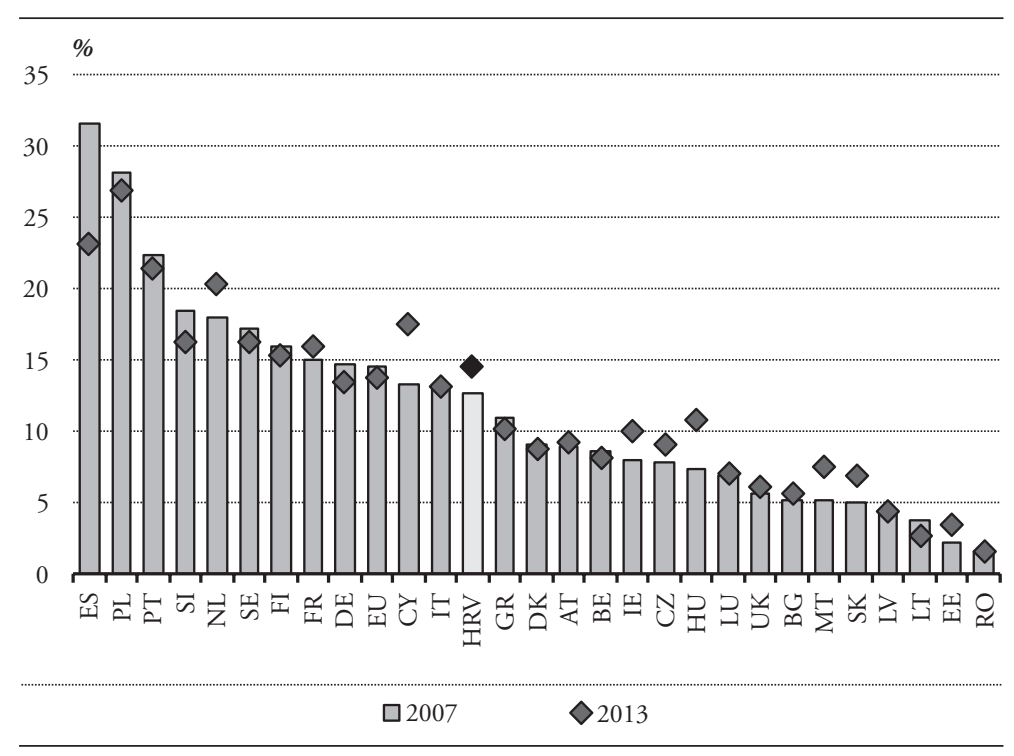

Source: Eurostat.

In contrast to developments in Croatia and the abovementioned countries, in several Member States a major share of the overall employment contraction was a consequence of a significant drop in the temporary employment. Specifically, a pronounced fall in the temporary employment was registered in Italy, France, Greece, Portugal and Spain. The destruction of temporary job positions was especially evident in Spain, which many authors (e.g., Jaumotte, 2011; Cazes and Laiglesia, 2014) highlight as a country with the most evident duality of the labor market. In the period between 2007 and 2013 the number of temporary workers declined by around 2 million, which represents more than 60 percent of the overall employment loss registered in Spain in that period (Table 5). 
Table 5: Employment Dynamics during the Recession, by Type of Employment Contract

\begin{tabular}{|c|c|c|c|c|}
\hline & \multicolumn{2}{|c|}{ Regular contracts } & \multicolumn{2}{|c|}{ Temporary contracts } \\
\hline & $\begin{array}{l}\text { Relative change, } \\
\text { in percent }\end{array}$ & $\begin{array}{l}\text { Absolute change, } \\
\text { in thousands }\end{array}$ & $\begin{array}{l}\text { Relative change, } \\
\text { in percent }\end{array}$ & $\begin{array}{l}\text { Absolute change, } \\
\text { in thousands }\end{array}$ \\
\hline Belgium & -0.5 & -18.6 & -1.8 & -5.7 \\
\hline Bulgaria & -10.7 & -339.4 & -27.3 & -39.3 \\
\hline Czech R. & -3.2 & -147.5 & 7.9 & 23.6 \\
\hline Denmark & -5.4 & -140.2 & -5.7 & -12.5 \\
\hline Germany & -0.1 & -30.1 & -1.3 & -64.4 \\
\hline Estonia & -14.3 & -88.4 & 30.8 & 4.4 \\
\hline Ireland & -14.7 & -284.8 & 11.4 & 15.8 \\
\hline Greece & -22.5 & -940.9 & -35.5 & -123.0 \\
\hline Spain & -8.9 & $-1,336.7$ & -39.3 & $-2,098.6$ \\
\hline France & -0.3 & -69.7 & -5.2 & -177.8 \\
\hline Croatia & -17.2 & -243.8 & 4.8 & 8.0 \\
\hline Italy & -1.8 & -376.2 & -6.0 & -137.8 \\
\hline Cyprus & 0.0 & 0.1 & -0.5 & -0.2 \\
\hline Latvia & -20.6 & -201.3 & 38.3 & 14.5 \\
\hline Lithuania & -13.0 & -179.1 & -41.9 & -19.2 \\
\hline Hungary & -4.8 & -174.8 & 11.7 & 29.0 \\
\hline Netherlands & -2.9 & -204.5 & -2.8 & -36.2 \\
\hline Austria & -0.6 & -20.8 & 1.1 & 3.4 \\
\hline Portugal & -12.4 & -485.8 & -16.2 & -141.9 \\
\hline Romania & -0.7 & -61.1 & -20.8 & -16.4 \\
\hline Slovenia & -7.5 & -61.7 & -17.2 & -25.4 \\
\hline Slovakia & -5.6 & -131.1 & 15.8 & 14.9 \\
\hline Finland & -3.9 & -83.6 & -1.1 & -3.5 \\
\hline Sweden & -1.3 & -51.6 & -7.9 & -50.8 \\
\hline UK & -2.5 & -685.6 & 9.4 & 124.4 \\
\hline
\end{tabular}

Note: The countries which did not register recession and/or employment drop after the outbreak of the global financial crisis are excluded.

Sources: Eurostat, Central Bureau of Statistics and author's calculation.

It could be argued that all potential risks stemming out from the dual labor market entirely materialized in Spain during the crisis $^{13}$. Namely, the impact of

13 Jimeno (2011) analyzes the main determinants of the dramatic deterioration of the labor market conditions in Spain after the start of the global financial crisis. Jimeno argues that besides dual labor market legislation the important factors which contributed to the employment drop were structural correction of output in construction and a very rigid collective bargaining system which prevented the necessary cost reduction from being realized through adjustment of nominal wages. 
recession was clearly borne relatively stronger by temporary employees, which suggests that they were in a markedly inferior position in terms of employment protection compared to permanent employees. Also, the dismissal of temporary workers contributed in a great extent to a cyclical decline in employment, which is also one of the common deficiencies of dual labor markets, as suggested by the literature.

\subsubsection{Potential Causes of Recent Adjustment in the Structure of Employment}

It is mentioned earlier that Croatia did not stand out with an especially high share of temporary employees in the years prior to the crisis. However, during the current recession noticeable changes in the employment flows have been registered, which in turn affects the relative shares of temporary and permanent workers in the total employment. More specifically, the data on flows in the unemployment register presented in Figure 4 show that during the current crisis, and especially since 2010, companies have increased their reliance on temporary employment contracts. These adjustments have been very significant. For example, in 2009, in which the economic contraction was especially pronounced, the number of exits from the unemployment register was very low, out of which around 100 thousand exits were caused by temporary hiring. Beginning with 2010, the frequency of temporary employment has been growing rapidly, and in 2014 the number of instances of temporary hiring reached 192 thousand. In the meantime, the number of exits based on permanent hiring has decreased drastically. To be exact, in 2014 there were only around 12 thousand instances of permanent hiring, compared to more than 25 thousand in the pre-crisis 2007. 
Figure 4: Hiring Based on the Type of Employment Contract

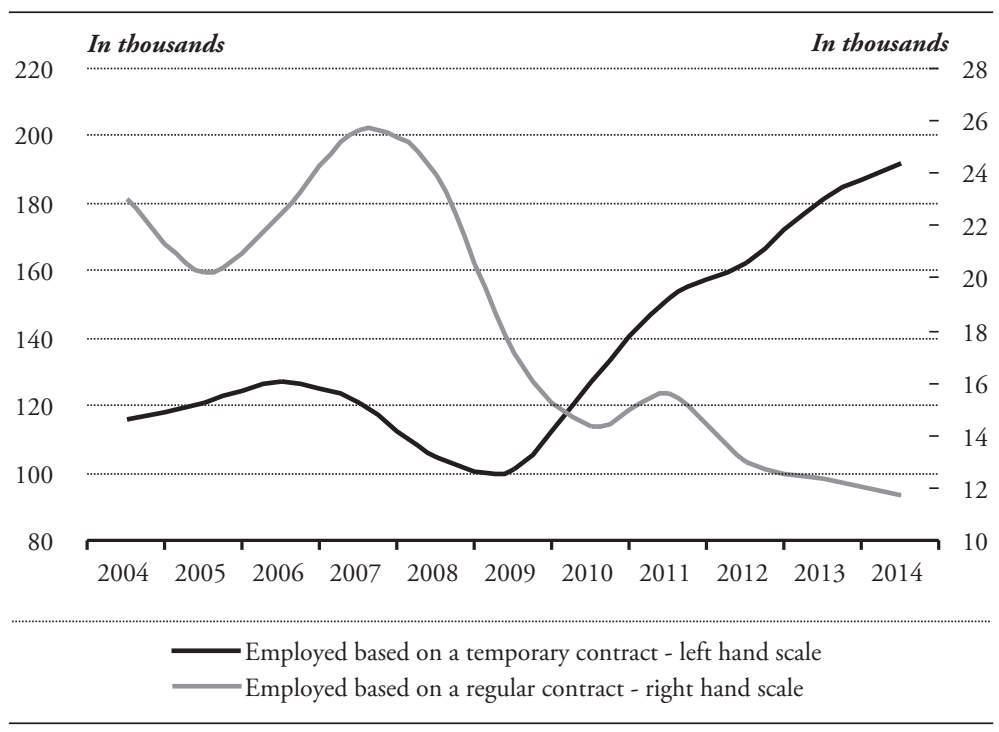

Source: Croatian Employment Service.

Such adjustments in the structure of new employment are not just a result of more pronounced seasonal hiring in services, but a general trend among companies. Namely, the data suggest that temporary hiring has increased significantly in the period 2010-2014 in basically every NACE activity, while hiring on permanent basis has slowed down (Tables 1 and 2 in the Appendix). The results of the Employers' survey also confirm that companies have been much more prone to temporary employment during the crisis $^{14}$.

The detailed data from the Labor Force Survey and the data on flows in the unemployment register clearly indicate that Croatian companies have started to substitute the use of permanent contracts with temporary employment contracts.

14 The results of the Employers' survey, which is conducted by the Croatian Employment Service on a yearly basis, suggest that during the recession companies have increased their reliance on temporary work contracts. For example, in the survey for 2008 employers announced that around 70 percent of new hiring in that year might be realized on a temporary basis. With the intensification of the recession the share of planned temporary employment in the overall planned employment has been steadily growing, so in the survey for 2014 the companies announced that the temporary employment could represent around 85 percent of the entire new hiring in that year. 
This trend is visible in almost all economic activities, so we can reject the possibility that the surge in temporary employment is a result of more pronounced seasonal employment. Low level of business confidence caused by the prolonged recession is the probable cause of greater reliance of companies on temporary employment. Namely, in the environment of low demand and high uncertainty, companies are more prone to hire workers using temporary contracts, since such contracts allow for higher flexibility to changing business conditions. Specifically, a company can very easily dismiss a temporary employee in case of a negative demand or supply shock by simply not renewing the temporary contract at its expiration.

\subsection{Is There Labor Market Duality in Croatia?}

The literature suggests that the distinct features of dual labor markets are the high share of temporary employees in total employment and the inferior position of those workers since they take a relatively harder burden of employment destruction during recessions. Moreover, high fluctuation in the number of temporary employees, which is a result of intensive temporary hiring in the expansionary phase, and afterwards a quick reduction in the number of temporary jobs during the phase of economic contraction, magnify the cyclical volatility of employment in dual labor markets.

Based on the analysis of the labor market developments over the recent years one cannot find strong evidence of the labor market duality in Croatia. Although Croatian labor market had all the features of a relatively rigid labor market according to international standards, at the beginning of the global financial crisis the share of temporary employees was relatively low. Given the low share of temporary workers in the total employment, Croatian companies were not able to adapt to deteriorating environment by dismissing only temporary workers, so almost the entire adjustment cost was taken by permanent employees. In such circumstances, it is not possible to argue that in Croatia the temporary employees took a disproportionally heavy burden of employment reduction, 
while the permanent employees were relatively isolated from the negative impact of the crisis. Meanwhile, in several Member States a major share of total employment decline was a consequence of reduction in temporary job positions. Spain especially stood out in that regard, given that prior to the crisis it had the highest share of temporary employees in the entire EU.

This chapter documents that since 2010 companies have been rapidly increasing the use of temporary contracts, which in turn results in the gradual increase in the share of temporary workers in the total employment. More frequent reliance on temporary contracts compared to the pre-crisis period could be a reflection of the higher risk aversion of firms in the environment of elevated uncertainty caused by the protracted recession. The relatively high level of employment protection for permanent employees most certainly affects such behavior of companies. However, a significant number of dismissals of permanent employees due to business reasons in recent years suggests that companies have succeeded in reducing employment regardless of the high employment protection. In that regard it is important to have in mind that most of the restrictive measures which complicate the dismissal process concern only companies with twenty or more employees. That means that smaller companies, which employ a high share of total workers in the economy, do not confront a lot of legal obstacles when engaging in employment cuts.

It is hard to predict whether the current structure of employment flows, which is dominated by temporary hiring, will remain after the economy finally approaches the recovery phase. In case this trend continues, the number of temporary employees would increase relative to the number of permanent employees. The temporary workers would be considered by the companies as the room for maneuver which could be used for adjustment purposes when the economic contraction occurs. In such circumstances the gap would emerge between the growing number of temporary employees and the permanent employees which enjoy much higher level of job security. Nevertheless, it is more likely that the companies' excessive reliance on temporary employment contracts is primarily a 
cyclical phenomenon which may disappear over the medium term, as soon as the economy reaches the path of sustainable recovery.

With regard to other potential sources of labor market duality in Croatia, during the current recession there has been an obvious segmentation of the labor market between the employees of the public sector, who were generally isolated from the negative effects of the crisis, and the employees of the private sector, who took almost the whole burden of the employment adjustment. Namely, as it is documented in this paper, the employment in economic activities dominated by the private sector shrank by more than 250 thousand in the period 2009-2013, while the number of employed persons in three activities dominated by the public sector, specifically public administration, education and health, mildly rose in the same period. In most of the other Member States the employment in public sector activities also remained relatively unchanged during recession. The situation was much different in Greece, Portugal and Latvia which have been implementing the macroeconomic adjustment programs that partly relied on layoffs of a certain percentage of public sector servants. The policymakers in Croatia did not opt for reduction of the public sector employment as part of the fiscal consolidation efforts, so the employment destruction was felt exclusively by the private sector employees.

\section{Conclusion}

The global financial crisis initiated a deep and persistent recession in Croatia which also heavily reflected on the labor market. Among the Member States of the EU, Croatia stands out as one of the countries which registered the strongest cumulative fall in economic activity and the worst labor market performance in the last couple of years. This paper illustrates that the scale of employment destruction varied to a great extent across countries, partly depending on how vulnerable the respective country was in the moment when the global crisis started to affect the EU economy. The Croatian economy was showing signs of 
severe vulnerabilities in the pre-crisis period. A steady accumulation of external imbalances, as demonstrated by high current account deficits and the surge in net external debt, was followed by the deepening of domestic imbalances, such as the rising private sector indebtedness and the overheating of the housing market. The existence of macroeconomic imbalances and considerable external refinancing needs made Croatian economy extremely vulnerable to potential financial turmoil. The negative impact of the global financial crisis materialized through sudden slowdown in capital inflows, abrupt contraction of international trade and plummeting business confidence, which in turn resulted in the significant fall in aggregate demand. The employment has been steadily declining since the start of recession in almost all economic activities. However, the employment loss was especially pronounced in activities such as construction and retail trade, which saw quick buildup of capacities in the pre-crisis period supported by the buoyant domestic demand. A dramatic employment drop in construction was also registered in other Member States which too were highly vulnerable in the eve of the global financial crisis.

The data on employment dynamics for the period since the start of recession do not provide clear indications of labor market duality in Croatia. Although the labor market legislation is mostly considered rigid, especially regarding provisions which stipulate high level of employment protection for permanent employees, the share of temporary employees prior to the global financial crisis was lower than the average value for the EU. The relatively low share of temporary workers meant that companies were not able to achieve the necessary cost reduction by dismissing only temporary workers when recession started. In such circumstances, permanent employment contracts did not guarantee job security and the intensification of the recession led to a dramatic fall in the number of permanent employees. In contrast to the situation in Croatia, in several Member States the temporary employees took a relatively heavier burden of employment reduction. This was especially the case in Spain. A very strong reduction in the number of temporary employees has demonstrated the obvious 
discrimination between workers depending on the type of their employment contract, whereby temporary employees were much more exposed to the risk of losing their jobs. Moreover, strong dismissal of temporary workers contributed to the overall cyclical volatility of employment in the last couple of years. Therefore, all risks which may exist in dual labor markets materialized in Spain during the current crisis.

Nevertheless, noticeable changes in the employment flows have been observed in Croatia during the current recession, which also affect the structure of total employment. Namely, the data on flows in the unemployment register show that the hiring based on temporary contracts is rapidly growing from 2010 onwards, while hiring on permanent basis is at the same time steadily declining. Such divergent trends resulted in a gradual increase in the share of temporary workers in the total employment. One explanation for more frequent use of temporary employment contracts is higher risk aversion of companies in the environment of uncertainty caused by the prolonged recession. Namely, the reliance on temporary workers allows for more flexibility since, in case of a negative shock, a company can easily dismiss such workers by not renewing the temporary contract at its expiration.

It is not possible to predict whether the companies will still excessively rely on temporary employment when economic activity strengthens. If the current structure of employment flows remains, the share of temporary employees would increase further which might result in the strengthening of the labor market duality. Nevertheless, it is more likely that the recent changes in the employment flows are primarily a cyclical phenomenon which might disappear once the economy reaches firmer recovery and business confidence increases. The new Labor code enacted in 2014, which has slightly reduced the employment protection for regular contracts, might stimulate firms to hire on permanent basis more frequently. 
One other sort of labor market duality was clearly identified during the current recession. It concerns the segmentation between the public sector employees, which were generally isolated from the negative effects of the recession, and the private sector employees, who felt the entire burden of the employment adjustment during the crisis. In this paper it is documented that in the economic activities dominated by the public sector, employment mildly increased since the start of the recession, while the remainder of the economy registered a reduction in the employment of around 250 thousand in the same period. In contrast to several Member States which decided to reduce the number of public sector servants as part of their fiscal consolidation efforts, the Croatian government has not implemented such measures and almost entire employment destruction was felt by the private sector. 


\section{Appendix}

Table 1: Exits from the Unemployment Register - Hiring under Temporary Contracts

\begin{tabular}{|c|c|c|c|c|c|c|}
\hline & 2009 & 2010 & 2011 & 2012 & 2013 & 2014 \\
\hline $\begin{array}{l}\text { (A) Agriculture, forestry and } \\
\text { fishing }\end{array}$ & 5361 & 5895 & 7785 & 7016 & 6894 & 7252 \\
\hline (B) Mining and quarrying & 209 & 219 & 279 & 262 & 278 & 215 \\
\hline (C) Manufacturing & 16786 & 21300 & 24254 & 25293 & 28848 & 31756 \\
\hline $\begin{array}{l}\text { (D) Electricity, gas, steam and } \\
\text { air conditioning supply }\end{array}$ & 90 & 99 & 118 & 146 & 175 & 343 \\
\hline $\begin{array}{l}\text { (E) Water supply; sewerage, } \\
\text { waste management and } \\
\text { remediation activities }\end{array}$ & 1422 & 2202 & 3683 & 3695 & 1590 & 1832 \\
\hline (F) Construction & 7517 & 10715 & 13800 & 14424 & 15887 & 17828 \\
\hline $\begin{array}{l}\text { (G) Wholesale and retail } \\
\text { trade; repair of motor vehicles } \\
\text { and motorcycles }\end{array}$ & 18368 & 21669 & 24419 & 24504 & 27626 & 29670 \\
\hline $\begin{array}{l}\text { (H) Transportation and } \\
\text { storage }\end{array}$ & 2461 & 3551 & 4360 & 5140 & 6077 & 6625 \\
\hline $\begin{array}{l}\text { (I) Accommodation and food } \\
\text { service activities }\end{array}$ & 18640 & 22459 & 25826 & 28881 & 34722 & 39373 \\
\hline $\begin{array}{l}\text { (J) Information and } \\
\text { communication }\end{array}$ & 747 & 1029 & 1155 & 1292 & 1772 & 2110 \\
\hline $\begin{array}{l}\text { (K) Financial and insurance } \\
\text { activities }\end{array}$ & 1188 & 1411 & 1486 & 1436 & 1470 & 1582 \\
\hline (L) Real estate activities & 401 & 551 & 595 & 710 & 955 & 1234 \\
\hline $\begin{array}{l}\text { (M) Professional, scientific } \\
\text { and technical activities }\end{array}$ & 2880 & 3786 & 4620 & 5143 & 5732 & 6255 \\
\hline $\begin{array}{l}\text { (N) Administrative and } \\
\text { support service activities }\end{array}$ & 6168 & 8328 & 9935 & 10868 & 12442 & 13863 \\
\hline $\begin{array}{l}\text { (O) Public administration and } \\
\text { defence; compulsory social } \\
\text { security }\end{array}$ & 2683 & 3705 & 6485 & 8996 & 9059 & 4275 \\
\hline (P) Education & 7731 & 9008 & 10417 & 11337 & 12005 & 13018 \\
\hline $\begin{array}{l}\text { (Q) Human health and social } \\
\text { work activities }\end{array}$ & 3592 & 4803 & 5862 & 5719 & 6804 & 6816 \\
\hline $\begin{array}{l}\text { (R) Art, entertainment and } \\
\text { recreation }\end{array}$ & 1508 & 1789 & 2214 & 2523 & 2757 & 2713 \\
\hline (S) Other service activities & 3157 & 3679 & 3733 & 4220 & 5053 & 4558 \\
\hline $\begin{array}{l}\text { (T) Activities of households as } \\
\text { employers }\end{array}$ & 165 & 589 & 891 & 902 & 1006 & 688 \\
\hline $\begin{array}{l}\text { (U) Activities of extra- } \\
\text { territorial organisations and } \\
\text { bodies }\end{array}$ & 26 & 15 & 15 & 25 & 20 & 30 \\
\hline Total & 101100 & 126802 & 151932 & 162532 & 181172 & 192036 \\
\hline
\end{tabular}

Source: Croatian Employment Service. 
Table 2: Exits from the Unemployment Register - Hiring under Regular Contracts

\begin{tabular}{|c|c|c|c|c|c|c|}
\hline & 2009 & 2010 & 2011 & 2012 & 2013 & 2014 \\
\hline $\begin{array}{l}\text { (A) Agriculture, forestry and } \\
\text { fishing }\end{array}$ & 437 & 370 & 426 & 314 & 299 & 233 \\
\hline (B) Mining and quarrying & 52 & 60 & 34 & 17 & 21 & 8 \\
\hline (C) Manufacturing & 2766 & 2353 & 2830 & 2272 & 2053 & 2288 \\
\hline $\begin{array}{l}\text { (D) Electricity, gas, steam and } \\
\text { air conditioning supply }\end{array}$ & 9 & 13 & 16 & 27 & 29 & 47 \\
\hline $\begin{array}{l}\text { (E) Water supply; sewerage, } \\
\text { waste management and } \\
\text { remediation activities }\end{array}$ & 69 & 83 & 152 & 97 & 58 & 38 \\
\hline (F) Construction & 1939 & 1601 & 1712 & 1262 & 1134 & 1031 \\
\hline $\begin{array}{l}\text { (G) Wholesale and retail } \\
\text { trade; repair of motor vehicles } \\
\text { and motorcycles }\end{array}$ & 3851 & 2950 & 3020 & 2235 & 2189 & 1710 \\
\hline $\begin{array}{l}(\mathrm{H}) \text { Transportation and } \\
\text { storage }\end{array}$ & 460 & 534 & 823 & 546 & 460 & 491 \\
\hline $\begin{array}{l}\text { (I) Accommodation and food } \\
\text { service activities }\end{array}$ & 1970 & 1455 & 1490 & 1203 & 1259 & 1141 \\
\hline $\begin{array}{l}\text { (J) Information and } \\
\text { communication }\end{array}$ & 334 & 239 & 289 & 249 & 295 & 264 \\
\hline $\begin{array}{l}\text { (K) Financial and insurance } \\
\text { activities }\end{array}$ & 276 & 225 & 254 & 218 & 174 & 141 \\
\hline (L) Real estate activities & 90 & 98 & 102 & 96 & 72 & 63 \\
\hline $\begin{array}{l}\text { (M) Professional, scientific } \\
\text { and technical activities }\end{array}$ & 799 & 794 & 793 & 793 & 865 & 629 \\
\hline $\begin{array}{l}\text { (N) Administrative and } \\
\text { support service activities }\end{array}$ & 888 & 851 & 819 & 807 & 669 & 634 \\
\hline $\begin{array}{l}\text { (O) Public administration and } \\
\text { defence; compulsory social } \\
\text { security }\end{array}$ & 343 & 186 & 350 & 308 & 328 & 377 \\
\hline (P) Education & 1005 & 846 & 863 & 1003 & 916 & 1098 \\
\hline $\begin{array}{l}\text { (Q) Human health and social } \\
\text { work activities }\end{array}$ & 660 & 690 & 871 & 868 & 925 & 1034 \\
\hline $\begin{array}{l}\text { (R) Art, entertainment and } \\
\text { recreation }\end{array}$ & 163 & 125 & 151 & 122 & 124 & 105 \\
\hline (S) Other service activities & 1038 & 638 & 405 & 381 & 378 & 284 \\
\hline $\begin{array}{l}\text { (T) Activities of households as } \\
\text { employers }\end{array}$ & 35 & 187 & 197 & 183 & 98 & 66 \\
\hline $\begin{array}{l}\text { (U) Activities of extra- } \\
\text { territorial organisations and } \\
\text { bodies }\end{array}$ & 2 & 5 & 2 & 2 & 2 & 3 \\
\hline Total & 17186 & 14303 & 15599 & 13003 & 12348 & 11685 \\
\hline
\end{tabular}

Source: Croatian Employment Service. 


\section{Literature}

Bakker, B. Bas and LiZeng, 2013, "Dismal Employment Growth in EU Countries: The Role of Corporate Balance Sheet Repair and Dual Labor Markets", IMF Working Papers, No. 179, August, Washington, DC: International Monetary Fund.

Bentolila, Samuel and Giuseppe Bertola, 1990, "Firing Costs and Labor Demand: How Bad is Eurosclerosis", The Review of Economic Studies, 57(3), pp. 381-402. http://dx.doi.org/10.2307/2298020

Bentolila, Samuel and Juan J. Dolado, 1994, "Labor Flexibility and Wages: Lessons from Spain", Economic Policy, 9(18), pp. 55-99. http://dx.doi. org/10.2307/1344458

Biondić, Iva, Silvia Crnić and Ana Martinis, 2002, "Indeks zakonske zaštite zaposlenja u Hrvatskoj i međunarodna usporedba", Financijska teorija i praksa, 26(4), pp. 837-860.

Blanchard, Olivier, Florence Jaumotte and Prakash Loungani, 2013, "Labor Market Policies and IMF Advice in Advanced Economies During the Great Recession”, IMF Staff Discussion Note, No. 2, March, Washington, DC: International Monetary Fund. http://dx.doi.org/10.2139/ssrn.2344550

Bluestone, Barry, 1970, "The Tripartite Economy: Labor Market and the Working Poor", Poverty and Human Resources, 5(4), pp. 15-35.

Boeri, Tito and Pietro Garibaldi, 2007, "Two Tier Reforms of Employment Protection: A Honeymoon Effect”, The Economic Journal, 117(521), pp. 357-385.

Boeri, Tito, 2010, "Institutional Reforms and Dualism in European Labor Markets", in Orley Ashenfelter and David Card, eds., Handbook of Labor Economics, 4(B), pp. 1173-1236, Amsterdam: Elsevier B.V. http://dx.doi. org/10.1111/j.1468-0297.2007.02060.x 
Cazes, Sandrine and Juan R. de Laiglesia, 2014, "Temporary Contracts, Labor Market Segmentation and Wage Inequality", Bonn: Institute for the Study of Labor, http://www.iza.org/conference_files/worldb2014/cazes_s4773.pdf (accessed June 16, 2015).

Central Bureau of Statistics, 2010, Labor Force Survey 2008, Zagreb: Central Bureau of Statistics.

Central Bureau of Statistics, 2015, Labor Force Survey 2013, Zagreb: Central Bureau of Statistics.

Croatian Employment Service, 2008, Employers'survey 2008, Zagreb: Croatian Employment Service.

Croatian Employment Service, 2010, Employers' survey 2010, Zagreb: Croatian Employment Service.

Croatian Employment Service, 2014, Employers' survey 2014, Zagreb: Croatian Employment Service.

Croatian National Bank, 2008, Financial Stability No. 1, Zagreb: Croatian National Bank.

Croatian National Bank, 2010, Annual Report 2009, Zagreb: Croatian National Bank.

Croatian National Bank, 2013, "An Analysis of Indicators of Labor Market Flexibility in Croatia", Box 1 in Bulletin No. 194, Zagreb: Croatian National Bank.

Croatian National Bank, 2014, "Reform of the Labor Act and Labor Market Flexibility in Croatia", Box 2 in Bulletin No. 209, Zagreb: Croatian National Bank.

Doeringer, Peter and Michael J. Piore, 1971, Internal Labor Markets and Manpower Analysis, Lexington, MA: Heath Lexington Books. 
European Commission, 2009, European Economic Forecast - Autumn 2009, Brussels: European Commission.

European Commission, 2013, Alert Mechanism Report 2014, Brussels: European Commission.

Franičević, Vojmir, 2011, "Croatia - Prolonged Crisis with an Uncertain Ending" in Daniel Vaughan-Whitehead, ed., Work Inequalities in the Crisis Evidence from Europe, pp. 143-197, Cheltenham and Geneve: Edward Elgar and International Labor Office. http://dx.doi.org/10.4337/9780857937513.00011

Garibaldi, Pietro and Filippo Taddei, 2013, "Italy: A Dual Labor Market in Transition”, ILO Employment Working Paper, No. 144, Geneve: International Labor Office.

Giersch, Herbert, 1985, "Eurosclerosis”, Kiel Discussion Paper, No. 112, October, Kiel: Kiel Institute for the World Economy.

Gordon, David M., 1972, Theories of Poverty and Underemployment, Lexington, MA: Heath Lexington Books.

Harrison, Bennett, 1973, Education, Training and the Urban Ghetto, Baltimore: The Johns Hopkins University Press.

Jaumotte, Florence, 2011, "The Spanish Labor Market in a Cross-Country Perspective”, IMF Working Papers, No. 11, January, Washington, DC: International Monetary Fund.

Jimeno, Juan F., 2011, “The Employment Crisis in Spain”, paper presented at the United Nations Expert Meeting "The Challenge of Building Employment for a Sustainable Recovery”, Geneve, June 23-24.

Kunovac, Marina, 2014, "Employment Protection Legislation in Croatia", Financial Theory and Practice, 38(2), pp. 103-138. http://dx.doi.org/10.3326/ fintp.38.2.2 
Matković, Teo, 2013, "Flexicurity trough Normalization? Changes in Scope, Composition, and Conditions in Temporary Employment in Croatia”, in Max Koch and Martin Fritz, eds., Nonstandard Employment in Europe: Paradigms, Prevalence and Policy Responses, pp. 84-102, Basingstoke: Palgrave Macmillan. http://dx.doi.org/10.1057/9781137267160.0015

Matković, Teo and Iva Biondić, 2003, "Reforma Zakona o radu i promjena indeksa zakonske zaštite zaposlenja”, Financijska teorija i praksa, 27(4), pp. 515528.

International Monetary Fund, 2014, Statement at the Conclusion of an IMF Staff Visit to the Republic of Croatia, Press Release No. 14/513, Washington, DC: International Monetary Fund.

Potočnjak, Željko, 2014, “Najznačajnije novine koje donosi novi Zakon o radu”, Hrvatska pravna revija, 14(9), pp. 14-30.

Rutkowski, Jan, 2003, “Analiza i prijedlozi poboljšanja tržišta rada u Hrvatskoj”, Financijska teorija i praksa, 27(4), pp. 495-513.

Saint-Paul, Gilles, 1997, Dual Labor Markets: A Macroeconomic Perspective, Cambridge, MA: MIT Press.

Sun, Yan, Pritha Mitra and Alejandro Simone, 2013, "The Driving Force behind the Boom and Bust in Construction in Europe", IMF Working Papers, No. 13/181, August, Washington, DC: International Monetary Fund.

Šošić, Vedran, 2004, "Regulation and Flexibility of the Croatian Labor Market", Working Paper, No. 48, June, Vienna: The Wiiw Balkan Observatory.

Tonin, Mirco, 2009, "Employment Protection Legislation in Central and East European Countries”, South-East Europe Review, 2009 (4), pp. 477-491.

Tomić, Iva and Polona Domadenik, 2012, "Matching, Adverse Selection and Labor Market Flows in a (Post)Transition Setting: the Case of Croatia," PostCommunist Economies, 24(1), pp. 39-72. http://dx.doi.org/10.1080/14631377.2 012.647969 
Vukšić, Goran, 2014, "Employment and Employment Conditions in the Current Economic Crisis in Croatia", Financial Theory and Practice, 38(2), pp. 103-138. http://dx.doi.org/10.3326/fintp.38.2.1

World Bank, 2010, Social Impact of the Crisis and Building Resilience, Zagreb: World Bank.

Zakon o radu, Narodne novine, No. 149/2009.

Zakon o izmjenama i dopunama Zakona o radu, Narodne novine, No. 73/2013.

Zakon o radu, Narodne novine, No. 93/2014. 